\title{
Cytotoxic and immunomodulatory effects of Ebenus boissieri Barbey on breast cancer cells
}

\author{
N. Imir ${ }^{1}$, E. Aydemir ${ }^{2}$, E. Simsek ${ }^{3}$, R.S. Gokturk², E. Yesilada ${ }^{4}$ and K. Fiskin ${ }^{2}$ \\ 1Department of Biology Education, Akdeniz University, Antalya, Turkey \\ ${ }^{2}$ Department of Biology, Akdeniz University, Antalya, Turkey \\ ${ }^{3}$ Department of Nutrition and Dietetics, Akdeniz University, Antalya, Turkey \\ ${ }^{4}$ Department of Pharmacognosy, Yeditepe University, Istanbul, Turkey \\ Corresponding author: N. Imir \\ E-mail: ngimir@akdeniz.edu.tr
}

Genet. Mol. Res. 15 (1): gmr.15017766

Received October 1, 2015

Accepted February 1, 2016

Published March 18, 2016

DOI http://dx.doi.org/10.4238/gmr.15017766

\begin{abstract}
We aimed to determine the cytotoxic and immunomodulatory effects of hydroalcoholic extracts of the roots and aerial parts of Ebenus boissieri (EB) on breast cancer MDA-MB231 cells and the non-cancerous human embryonic kidney cell line, 293T. Cell viability was determined by MTT assay, trypan blue exclusion, and Live/Dead Viability/Cytotoxicity assay. Apoptosis was evaluated by measuring the activity of caspase-2, 3, 6, 8 , and 9. Tumor necrosis factor (TNF)- $\alpha$ and interferon (IFN)- $\gamma$ release was assayed by ELISA, and protein expression of caspase-3, TNF- $\alpha$, and IFN- $\gamma$ was determined by western blot. The results of this study revealed that MDAMB231 cell viability was reduced in a dose-dependent manner by the aerial and root extract of EB at $72 \mathrm{~h}$ with a half-maximal inhibitory concentration $\left(\mathrm{IC}_{50}\right)$ of $41.1 \pm 2.76$ and $65 \pm 1.09 \mu \mathrm{g} / \mathrm{mL}$, respectively. In contrast, neither the aerial nor the root extracts of this plant inhibited the proliferation of 293T cells at doses up to $1000 \mu \mathrm{g} / \mathrm{mL}$. There was a time-dependent increase in caspase activity, especially caspase- 3 and caspase-9. The levels of TNF- $\alpha$ and IFN- $\gamma$ significantly increased in MDA-MB231 cells treated with aerial extract. In conclusion, the extracts of EB induced apoptosis in breast cancer cells by altering the levels of caspases, TNF- $\alpha$, and IFN- $\gamma$. The components
\end{abstract}


and precise modes of action of EB have not yet been determined. However, potential antitumor and immunomodulatory activity was observed along with selectivity against cancer cells in vitro, suggesting that hydroalcoholic extracts of this plant are worthy of additional study.

Key words: Apoptosis; Caspases; Ebenus boissieri; IFN- $\gamma$; TNF- $\alpha$

\section{INTRODUCTION}

Cancer is a major public health problem worldwide. Breast cancer is the third most common cause of cancer-related deaths, and is the second most common cancer in women worldwide (Engel et al., 2011; Carvalho et al., 2012). Breast cancer-related mortality rates continue to increase every year. Conventional therapies for breast cancer such as anti-hormonal therapy, and chemoand radiotherapy have several side effects (Natarajan et al., 2011). Considering these effects, new strategies and treatment modalities are required to effectively treat patients with breast cancer.

Consequently, the potential anti-tumor activity of medicinal plants has recently been explored in many studies (Yang et al., 2008; Leong et al., 2011; Aydemir et al., 2011; Tsai et al., 2012; Ooi et al., 2013; Pacifico et al., 2013; Xiong et al., 2015). Since traditional Anatolian medicine makes extensive use of plants as useful pharmaceuticals, Turkey is considered a promising region for discovering new plant products. The genus Ebenus belongs to the Fabaceae family and was revised by Huber-Morath in the Flora of Turkey (Huber-Morath, 1970). Owing to their close resemblance to Astragalus species, they are often referred to by similar vernacular names by the local inhabitants. Experimental and clinical investigations on Astragalus membranaceus roots have revealed that the extracts possess significant effects against various types of cancer (Ren et al., 2013). Therefore, we focused on the capability of Ebenus boissieri Barbey (EB) extracts to induce apoptosis in the present study. We also evaluated the cytotoxic activity of this plant towards cancerous MDA-MB231 cells and non-cancerous 293T cells. To the best of our knowledge, this is the first report indicating any pharmacological properties of EB on MDA-MB231 cells.

\section{MATERIAL AND METHODS}

\section{Plant material and extraction}

EB is a 50- to $60-\mathrm{cm}$ tall perennial herb with yellow flowers. It is endemic to Turkey, where it only grows in Antalya Province. The roots and flowering aerial parts of EB were collected in Turkey, C3 Antalya, Korkuteli district (36 $\left.56^{\prime} 51^{\prime \prime} \mathrm{N}, 30^{\circ} 09^{\prime} 41^{\prime \prime E}\right)$, from stony hillsides and steppe located about $1290 \mathrm{~m}$ above sea level in the middle of June 2008. A voucher specimen was deposited at AKDU (Herbarium of the Biology Department of Akdeniz University) as Göktürk 7201. Either dried roots or aerial parts of EB were powdered and individually macerated in $80 \%$ ethanol for two days at room temperature. The extracts were then filtered and evaporated to dryness under reduced pressure to yield a root extract $(20.2 \% \mathrm{w} / \mathrm{w})$ and an extract of aerial parts $(32.7 \% \mathrm{w} / \mathrm{w})$.

\section{Cell culture}

MDA-MB231 cells (ATCC ${ }^{\circledR} \mathrm{HTB}-26^{\mathrm{TM}}$ ) were cultured in DMEM (Gibco, Carlsbad, 
CA, USA) containing $10 \%$ fetal bovine serum (FBS), $10 \mu \mathrm{g} / \mathrm{mL}$ gentamicin, and $5 \%$ sodium pyruvate. The 293T cells were maintained in RPMI 1640 supplemented with $10 \%$ FBS, 100 $\mathrm{mg} / \mathrm{L}$ streptomycin, and $100 \mathrm{mU} / \mathrm{L}$ penicillin. The cells were incubated under $5 \% \mathrm{CO}_{2}$ with $95 \%$ humidity at $37^{\circ} \mathrm{C}$.

\section{MTT assay and cell viability assay}

Cell proliferation was estimated using the MTT assay. The cells were seeded at $1 \times 10^{4}$ cells per well in $200 \mu \mathrm{L}$ complete medium on 96-well plates (Aydemir et al., 2011). Cells were treated with various concentrations $(0.01-1000 \mu \mathrm{g} / \mathrm{mL})$ of hydroalcoholic aerial and root extracts. Doxorubicin- $\mathrm{HCl}$ was used as positive control. Cytotoxic effects were analyzed at 24,48 , and $72 \mathrm{~h}$. The half-maximal inhibitory concentration $\left(\mathrm{IC}_{50}\right)$ of each extract was derived by a nonlinear regression model (curve-fit) based on sigmoidal dose response curve (variable slope) and computed using GraphPad Prism, version 4.00 (GraphPad Software, San Diego, CA, USA). Growth inhibition was determined using the following formula: Growth inhibitory activity $(\%)=[1-(\mathrm{OD}$ value of sample / OD value of control group)] $\times 100$.

The Live/Dead Viability/Cytotoxicity kit for mammalian cells (Invitrogen, Eugene, OR, USA) was used to determine cell viability. Briefly, the cells were seeded at $1 \times 10^{4}$ cells per well on 96well plates containing $200 \mu \mathrm{L}$ complete medium and allowed to attach for $24 \mathrm{~h}$. The same protocol described above was used for the treatment of cells with the extracts. Following the manufacturer protocol, cells were double stained with two probes, enabling the simultaneous determination of live and dead cells in a sample. Fluorescence intensity was measured on a LS55 Luminescence Plate Reader (PerkinElmer Inc., Waltham, MA, USA) at 485-530 nm excitation and 630-645 nm emission wavelengths. Trypan blue exclusion was used as a second viability assay. The percentage of viable cells (\%) was calculated as: [(the number of live plus dead cells - the number of dead cells) / the number of live plus dead cells] x 100 (Aydemir et al., 2011).

\section{Determination of caspase activation}

Caspase colorimetric protease assay sampler kit (Invitrogen Corp., Camarillo, CA, USA) was used to determine the activity of caspase $-2,3,6,8$, and 9 . In brief, cells $\left(5 \times 10^{5}\right.$ cells/well on 6 -well plates) were collected and lysed after treatment. The protein concentrations of the samples were determined using a Bio-Rad assay kit (Bio-Rad Lab, Hercules, CA, USA) and measured against bovine serum albumin standards. Caspase activity was measured using an ELISA Plate Reader (MultiScan Spectrum, Thermo LabSystem, Chantilly, VA, USA) following the manufacturer protocol. Foldinduction of caspase activity was determined by direct comparison with the levels in untreated control cells (Nikhil et al., 2014).

\section{ELISA assays for tumor necrosis factor (TNF)- $\alpha$ and interferon (IFN)- $\gamma$}

Release of TNF- $\alpha$ and IFN- $\gamma$ was assayed by enzyme linked immunosorbent assay (ELISA) as described by the manufacturer (Invitrogen Corp., Camarillo, CA, USA). Human TNF- $\alpha$ and IFN- $\gamma$ were diluted and used as standards. Serial dilutions from 1000 to $15.6 \mathrm{pg} / \mathrm{mL}$ were used to establish the standard curve. Average results from four independent experiments compared untreated and treated cells. 


\section{Western blot}

To determine the effects of EB on caspase-3, TNF- $\alpha$, and IFN- $\gamma$ protein levels, cell homogenates were analyzed by standard western blotting techniques (Papi et al., 2013). The protein concentration of the cell homogenates was assayed using the Bio-Rad protein assay, and 25- $\mathrm{ng}$ samples of homogenate protein were separated on a $10 \%$ acrylamide gel by SDS-PAGE and then transferred to polyvinylidene difluoride membranes (Hybond-P, Amersham Pharmacia Biotech, Piscataway, NJ, USA) using a semidry transfer apparatus. The membranes were blocked and then probed with anticaspase-3, anti-TNF- $\alpha$, and anti-IFN- $\gamma$ antibodies (sc-2710281, sc-1350, and sc-59993, respectively, Santa Cruz Biotechnology, Santa Cruz, CA, USA). The primary antibodies were diluted 1:100 and the horseradish peroxidase-conjugated mouse anti-human IgG secondary antibody (sc-2005 Santa Cruz Biotechnology, Santa Cruz, CA, USA) was diluted 1:2000. The membranes were washed, and blots were developed using ECL Plus kit (Amersham Biosciences, Piscataway, NJ, USA) and exposed to X-ray film for 2-30 s. Molecular weight standards (sc-2035, Santa Cruz Biotechnology) were used to determine the molecular weights of visualized bands. Beta actin was used as a protein loading control.

\section{Statistical analysis}

All values are reported as means \pm SE. Data were analyzed by one-way ANOVA with Dunnett's Multiple Comparison Test to compare groups with control or by the Student $t$-test to evaluate statistical differences between two sample groups. A P value of $<0.05$ was considered statistically significant.

\section{RESULTS}

The present study focused on the possible cytotoxic, apoptotic, and immunomodulatory effects of hydroalcoholic extracts of EB on MDA-MB231 breast cancer cells.

\section{Cytotoxic effects of EB on MDA-MB231 cells}

The MTT assay has been used to determine cell viability in assays of cell proliferation and cytotoxicity (Shoemaker et al., 2004). Many herbal medicines and phytochemicals have been analyzed for their cytoprotective effects using the MTT assay (Horokova et al., 2003). In the present study, the cytotoxic effects of various concentrations $(0.01-1000 \mu \mathrm{g} / \mathrm{mL})$ of hydroalcoholic aerial and root extracts of EB on MDA-MB231 and 293T cells were assessed using the MTT assay. Firstly, to compare the antiproliferative effects of aerial and root extracts of EB on normal cells, the growth inhibition ratio for 293T cells was determined. As shown in Figure $1 A$ and $B$, root extract more obviously inhibited the growth of $293 \mathrm{~T}$ cells than aerial extract, but aerial and root extracts had no direct cytotoxic effects on noncancerous 293T cells $(P>0.05)$. We then examined the antiproliferative effects of aerial and root extracts on MDA-MB231 cells. Cell viability was determined 24,48 , and $72 \mathrm{~h}$ after treatment and decreased in a dose-dependent manner. The $\mathrm{IC}_{50}$ of aerial and root extracts for MDA-MB231 cells were $165 \pm 1.72,76.3 \pm 2.05,41.1 \pm 2.76 \mu \mathrm{g} /$ $\mathrm{mL}$, and $243 \pm 6.75,94 \pm 4.49,65 \pm 1.09$ at 24, 48, and $72 \mathrm{~h}$, respectively (Figure 1C and D). These findings indicate that the effects of both aerial and root extracts were dose- and time-dependent manner. As can be seen from the MTT results, both aerial and root extracts significantly inhibited the proliferation of breast cancer cells $(P<0.001)$ and the aerial extract was more effective on MDA-MB231 cells than the root extract (Figure 2A and B), which is an important finding of the 
study. Given the fact that no cytotoxic effect was observed against normal cells, our data clearly indicate that EB exerts a selective antiproliferative activity against breast cancer cells.
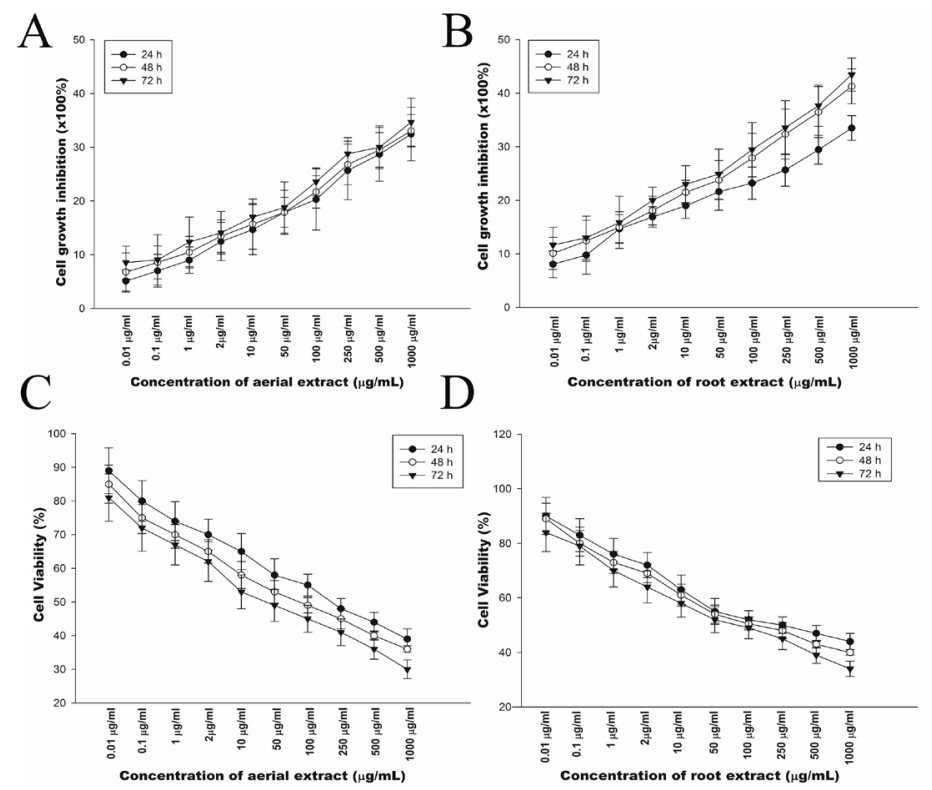

Figure 1. In vitro inhibition of cell growth. Dose-response of 293T cells to hydroalcoholic aerial and root extracts. The 293T cells were incubated with increasing concentrations $(0.01-1000 \mu \mathrm{g} / \mathrm{mL})$ of hydroalcoholic aerial $(\mathbf{A})$ and root extracts (B) for 24, 48, and $72 \mathrm{~h}$. Cytotoxic effects of hydroalcoholic aerial (C) and root (D) extracts against MDAMB231 breast cancer cell line for 24,48 , and $72 \mathrm{~h}$. Cell proliferation was determined by MTT assay. The graphs are plotted as percent inhibition compared with control cells. Results are representative of four independent experiments with eight replicates and are reported as means \pm SE.
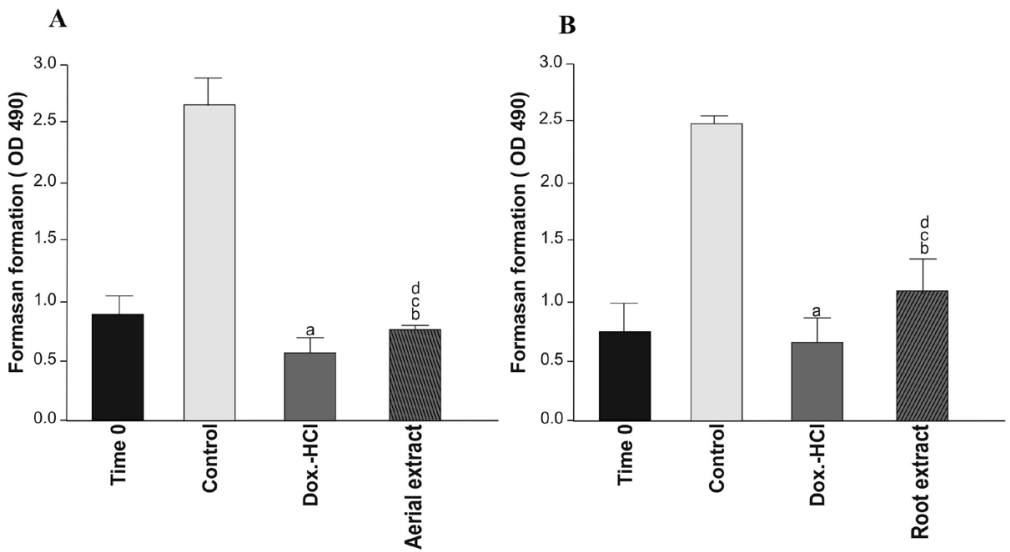

Figure 2. Effect of hydroalcoholic aerial and root extracts on growth of MDA-MB231 cells. Cells were treated with 40 $\mu \mathrm{g} / \mathrm{mL}$ aerial extract $(A)$ and $65 \mu \mathrm{g} / \mathrm{mL}$ root extract (B). Doxorubicin- $\mathrm{HCl}$ was used as a positive control. Cell growth was determined after $72 \mathrm{~h}$ using MTS solution. Time 0 represents the level of formasan formation in the cells before treatment. Viability of the cells was measured by MTT assay. Each bar represents time-dependent changes in viability. Results are representative of four independent experiments with eight replicates and are presented as means \pm SE; aP $<0.01$ and ${ }^{b} \mathrm{P}<0.001$, significantly different from control group, and respectively; ${ }^{\mathrm{C}} \mathrm{P}<0.05$ and ${ }^{\mathrm{d}} \mathrm{P}<0.01$, significantly different from doxorubicin-HCl-treated group at same incubation time. 
To confirm the effects of EB extracts on cell growth, the trypan blue exclusion assay was performed. The number of dead and live cells was determined $72 \mathrm{~h}$ after treatment. The number of live cells decreased in both the aerial and root-extract treatment groups. Cell death was observable on microscopic images of 293T cells (Figure 3) and MDA-MB231 cells (Figure 4), with an abundance of seemingly condensed apoptotic cells and cell fragments in the cells treated with aerial extract (Figures 3C, 4C) as well as in the cells treated with root extract (Figures 3D and 4D). The total cell number was affected by these treatments, which indicates that the extracts not only induced cell death but also inhibited cell proliferation. The effects of aerial and root extracts of EB on the two cell types were compared. The percentage decrease in cell survival was calculated for each independent experiment and the average of three experiments is shown in Table 1. Similar results were obtained for the cell viability assay, which was used as a marker of both viable and non-viable cells (Table 2).

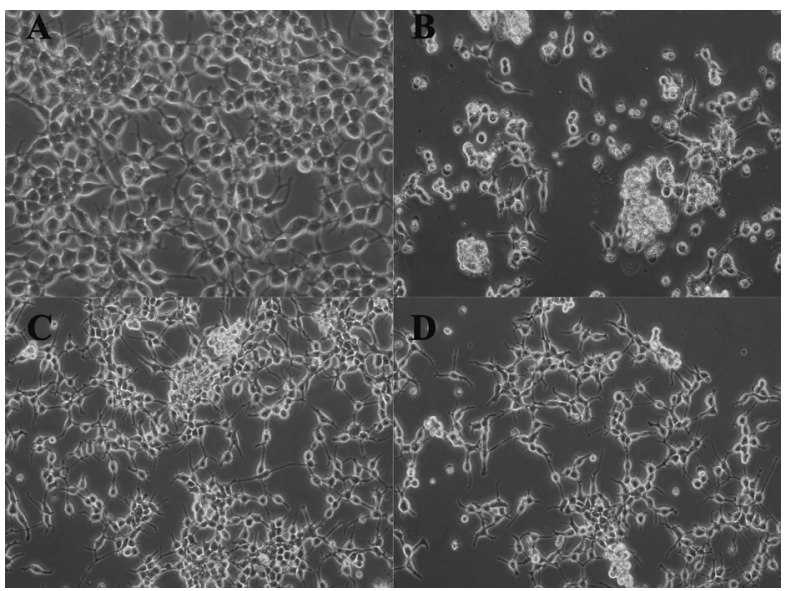

Figure 3. After seeding on 12-well plates (50,000 cells/well), the number of live and dead 293T cells was determined by the trypan blue exclusion assay after 72-h culture. Untreated control cells $(\mathbf{A})$ and cells treated with doxorubicin$\mathrm{HCl}(\mathbf{B})$, aerial extract (C), or root extract (D) were photographed using phase-contrast microscopy (Olympus-IX71).

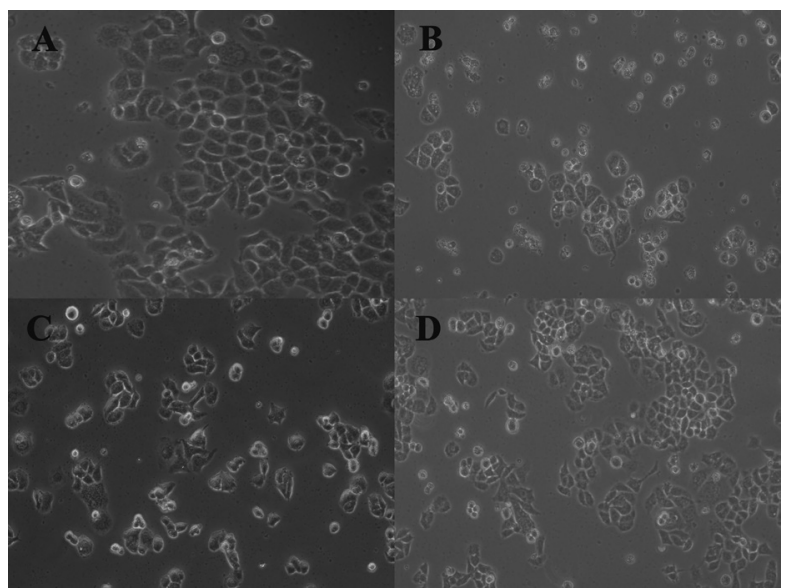

Figure 4. MDA-MB231cells were seeded on 12-well plates (50,000 cells/well) and the number of live and dead cells was determined by the trypan blue exclusion assay. Untreated control cells $(\mathbf{A})$ and cells treated with doxorubicin- $\mathrm{HCl}(\mathbf{B})$, aerial extract (C), or root extract (D) were photographed using phase-contrast microscopy (Olympus-IX71) after 72-h culture. 
Table 1. Results of trypan blue exclusion test.

\begin{tabular}{l|c|c|c}
\hline & Aerial extract & Root extract & Doxorubicin-HCl \\
\hline 293T & $16.25 \pm 9.66$ & $24.53 \pm 11.07$ & $82.34 \pm 14.50$ \\
\hline MDA-MB231 & $68.40 \pm 12.34$ & $57.49 \pm 10.73$ & $76.38 \pm 11.35$ \\
\hline
\end{tabular}

Experiments were repeated three times with eight replicate wells. The percent decrease in cell survival was determined by the following formula: \% decrease in cell survival $=100$ - (number of live cells in $40 \mu \mathrm{g} / \mathrm{mL}$ aerial extract, $65 \mu \mathrm{g} / \mathrm{mL}$ root extract, or $1 \mu \mathrm{g} / \mathrm{mL}$ doxorubicin-HCl-treated group / number of live cells in untreated control group) $\times 100$.

Table 2. Results of cell viability assay.
\begin{tabular}{l|c|c|c|c}
\hline & & Aerial extract & Root extract & Doxorubicin- $\mathrm{HCl}$ \\
\hline $293 T$ & DC $(\%)$ & $14.55 \pm 8.47$ & $23.18 \pm 12.73$ & $79.82 \pm 9.31$ \\
\hline MDA-MB231 & DC $(\%)$ & $68.70 \pm 10.51$ & $55.42 \pm 11.46$ & $83.29 \pm 10.47$ \\
\hline
\end{tabular}

Experiments were repeated three times with eight replicate wells and the percentage of dead cells was calculated as described in the technical datasheet for the Live/Dead Viability/Cytotoxicity kit for mammalian cells (Invitrogen). DC, dead cell.

\section{Apoptotic effects of EB on MDA-MB231 cells}

We also examined the effects of EB extracts on caspases, key proteins that modulate the apoptotic response (Alnemri et al., 1996; Stennicke and Salvesen, 2000). There was a timedependent increase in the activity of all caspases, especially caspase- 3 and 9 . According to the assay results, exposure to the aerial extract led to fold increases of 1.48, 5.19, 2.76, 3.67, and 4.71 in the activity of caspases-2, 3, 6, 8, and 9, respectively (Figure 5A). Similarly, exposure to the root extract caused 1.06-, 4.50-, 2.1-, 2.35-, and 3.45-fold increases in caspase-2, 3, 6, 8, and 9 activity, respectively (Figure 5B). Caspase- 3 is a key effector of apoptosis, whose activation is mediated by initiator caspases such as caspase-9 (Budihardjo et al., 1999). We found that the aerial extract induced higher levels of caspase-3 activity over time in MDA-MB231 breast cancer cells than the root extract, and this activation seems to be the consequence of caspase- 9 activation. Moreover, the lysates of treated cells were subjected to western blot analysis and the results showed that the protein expression of inactive pro-caspase- 3 was significantly decreased by its transformation to the active form. Hence, the ability of EB extracts to increase the intrinsic activation of caspase-3 in MDA-MB231 cells suggests a potential role for this plant extracts in breast cancer therapy.

\section{Immunomodulatory effects of EB on MDA-MB231 cells}

According to our ELISA assay results, the levels of TNF- $\alpha$ and IFN- $\gamma$ were significantly increased $(P<0.001)$ in the supernatants of MDA-MB231 cells treated with aerial extract compared with untreated cells (Figure $5 C$ and D). Similarly, western blot analysis clearly shows that incubation of MDA-MB231 cells with EB resulted in increased protein expression of TNF- $\alpha$ and IFN- $\gamma$ (Figure 6). 


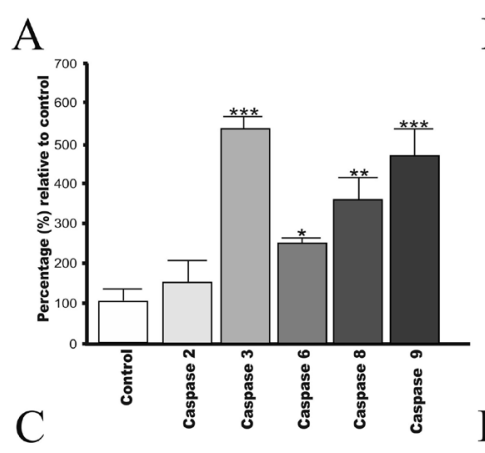

\section{$\mathrm{B}$}
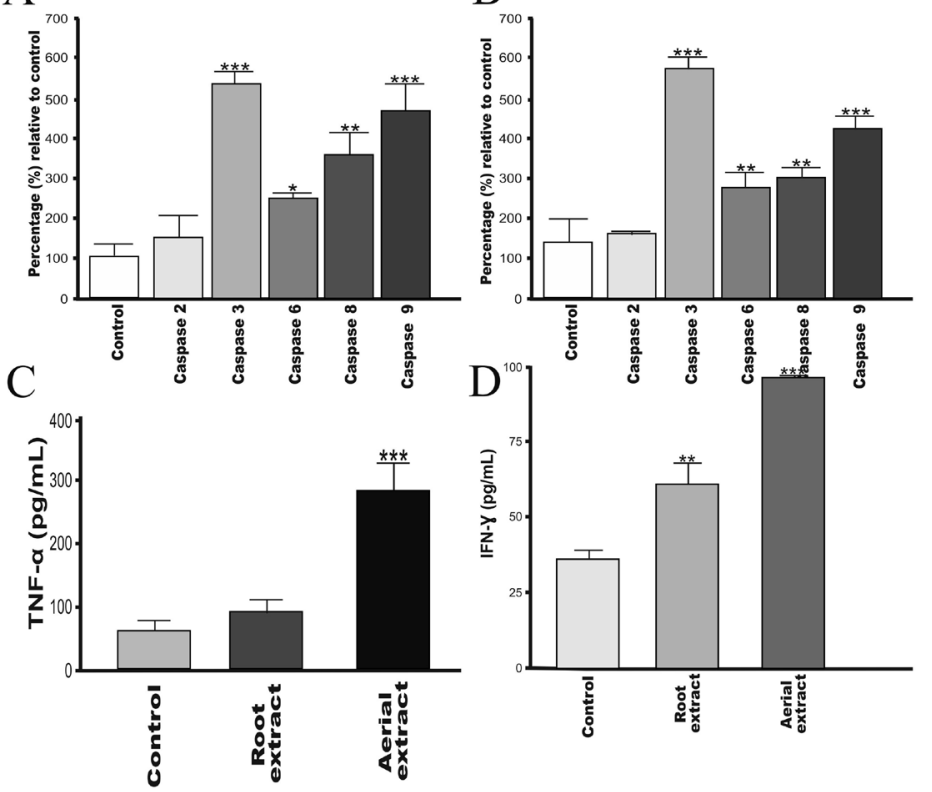

Figure 5. Effects of aerial and root extracts on the activity of apoptosis-related proteins and the protein expression of markers of inflammation determined by ELISA assays. Both aerial (A) and root (B) extracts induced the activity of all caspases, especially caspase-3 and 9, in MDA-MB231 breast cancer cells. Greater protein expression of TNF- $\alpha$ (C) and IFN- $\gamma(\mathbf{D})$ was induced in breast cancer cells treated with aerial extract than those treated with root extract. Data are reported as means \pm SEM of four independent experiments. ${ }^{*} P<0.05$, ${ }^{* *} P<0.01$, and ${ }^{* * *} P<0.001$, significantly different compared with the control group; Student's $t$-test.

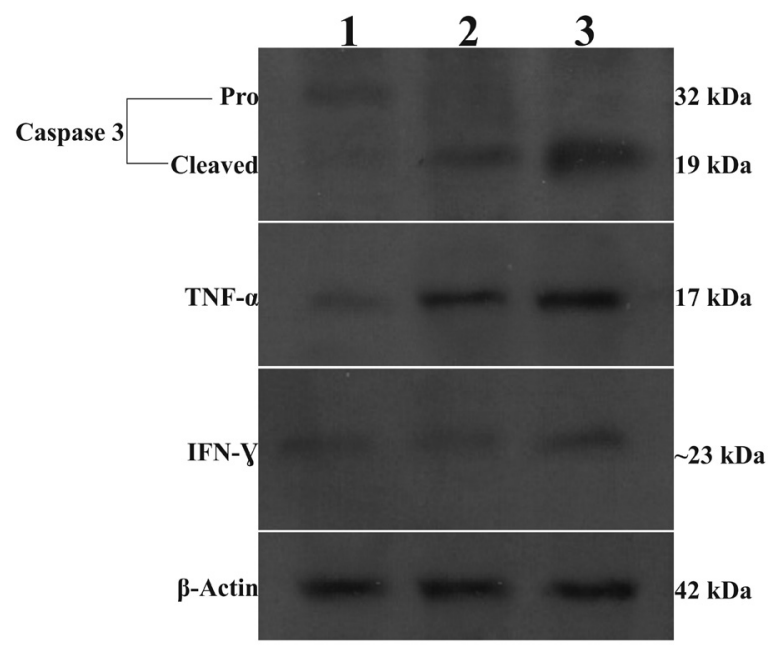

Figure 6. Lysates from MDA-MB231 cells incubated with root (lane 2) or aerial (lane 3) extracts were analyzed by western blotting for the protein expression of caspase-3, TNF- $\alpha$, and IFN- $\gamma$. Aerial- or root-treated cells are positive for cleaved (activated) caspase-3, whereas untreated (lane 1) cells have no cleaved caspase-3. $\beta$-Actin was used as a loading control. 


\section{DISCUSSION}

Apoptosis is a major form of cell death and plays an important role in many diverse processes. The deregulation of apoptotic signaling pathways is central to almost all cancer types. Hence, the induction of apoptosis is considered an efficient strategy to eradicate tumor cells (Levine et al., 2001; Brown and Attardi, 2005). Investigating plants and plant-derived products as potential inducers of apoptosis has become one of the major strategies in the study of anticancer drugs. Moreover, experimental and clinical investigations on the roots of Astragalus membranaceus (another member of the Fabaceae family) have revealed that these extracts possess significant effects against various types of cancer (Ren et al., 2013). Therefore, this study focused on the possible cytotoxic, apoptotic, and immunomodulatory effects of hydroalcoholic extracts of EB, a member of Fabaceae family, on MDA-MB231 breast cancer cells. This study provides the first detailed examination of the cytotoxic activity of EB extracts on MDA-MB231 breast cancer cells and 293T human embryonic kidney cells. It is well known that 293T cells used in experiments as a control more closely resemble non-cancerous cells. Our results showed that both aerial and root extracts strongly suppressed the growth of breast cancer cells, while normal cells were almost insensitive. This result indicates the selective toxicity of EB, especially the aerial extract, against cancer cells. The low $\mathrm{IC}_{50}$ values indicate that the cytotoxic effects of the extracts are more potent than those of various extracts from other members of the Fabaceae family are (Kim et al., 2008; Yu et al., 2008). Wang and Jiao (2001) reported that the ability of compounds to efficiently induce apoptosis in cancer cells indicates anticancer activity. Similarly, the results presented here showed a decrease in the percentage of viable cells, and both EB extracts effectively inhibited the proliferation of breast cancer cells. Therefore, in light of the results presented in this study, it is conceivable that EB extracts may possess antiproliferative properties and this plant can be considered to have potential as a natural therapeutic treatment for breast cancer.

The results obtained from ELISA and western-blot analysis for TNF- $\alpha$ and IFN- $\gamma$ indicate that the antitumor effects of these extracts might be implemented by strengthening the immune response. TNF- $\alpha$ and IFN- $\gamma$ are cytokines related to immunity. IFN- $\gamma$ is a major immunoregulatory molecule with antitumor and immunomodulatory properties (Blankenstein and Qin, 2003) and inhibits cell proliferation and angiogenesis in the tumor microenvironment. TNF- $\alpha$ also plays a pivotal role in host defenses and can induce the expression of a number of other inflammatory mediators (Baugh and Bucala, 2001). One of the most prominent characteristics of TNF- $\alpha$ is its ability to cause apoptosis of tumor-associated cells, resulting in tumor necrosis (Lejeune et al., 2006). The potency of apoptosis induction in tumor cells can be improved by incremental increases in TNF- $\alpha$ secretion (Folmer et al., 2009; Lee et al., 2009; Min et al., 2010). Finally, in accordance with our results, we suggest that EB extracts may modify not only the induction of tumor cell death and inhibition of cell proliferation, but also modify the immune response to tumor cells.

In conclusion, the main goal of this study was to investigate the potential anticancer activity of EB extracts against breast cancer cells. Taken together, the results of this study revealed that the hydroalcoholic extracts of EB induce apoptosis in breast cancer cells by altering the levels of caspases, TNF- $\alpha$, and IFN- $\gamma$. The potential antitumor and immunomodulatory activity of EB, along with the selectivity against cancer cells observed in vitro, suggest that hydroalcoholic extracts of this plant are worthy of additional study. Further chemical and pharmacological investigations to identify the active constituents of this plant and to screen their mechanisms of action are recommended for anticancer drug discovery. 


\section{Conflicts of interest}

\section{The authors declare no conflict of interest. ACKNOWLEDGMENTS}

Research supported by the Scientific Research Project Coordination Unit of Akdeniz University (Project \#2012.06.0115.032) and Akdeniz University, Science Faculty, Department of Biology. We are grateful to the Akdeniz University, the Faculty of Medicine, and the Department of Histology and Embryology for the assistance and technical support in the use of the phase-contrast microscope (Olympus-IX71).

\section{REFERENCES}

Alnemri ES, Livingston DJ, Nicholson DW, Salvesen G, et al. (1996). Human ICE/CED-3 protease nomenclature. Cell $87: 171$. http://dx.doi.org/10.1016/S0092-8674(00)81334-3

Aydemir EA, Oz ES, Göktürk RS, Ozkan G, et al. (2011). Glycyrrhiza flavescens subsp. antalyensis exerts antiproliferative effects on melanoma cells via altering TNF- $\alpha$ and IFN- $\alpha$ levels. Food Chem. Toxicol. 49: 820-828. http://dx.doi. org/10.1016/j.fct.2010.12.003

Baugh JA and Bucala R (2001). Mechanisms for modulating TNF alpha in immune and inflammatory disease. Curr. Opin. Drug Discov. Devel. 4: 635-650.

Blankenstein T and Qin Z (2003). Chemical carcinogens as foreign bodies and some pitfalls regarding cancer immune surveillance. Adv. Cancer Res. 90: 179-207. http://dx.doi.org/10.1016/S0065-230X(03)90006-6

Brown JM and Attardi LD (2005). The role of apoptosis in cancer development and treatment response. Nat. Rev. Cancer 5: 231-237.

Budihardjo I, Oliver H, Lutter M, Luo X, et al. (1999). Biochemical pathways of caspase activation during apoptosis. Annu. Rev. Cell Dev. Biol. 15: 269-290. http://dx.doi.org/10.1146/annurev.cellbio.15.1.269

Carvalho AJS, Ishikawa T and Gouvea CMCP (2012). Aqueous extract of Plinia edulis leaves: Antioxidant activity and cytotoxicity to human breast cancer MCF-7 cell line. S. Afr. J. Bot. 81: 1-7. http://dx.doi.org/10.1016/j.sajb.2012.03.010

Engel N, Oppermann C, Falodun A and Kragl U (2011). Proliferative effects of five traditional Nigerian medicinal plant extracts on human breast and bone cancer cell lines. J. Ethnopharmacol. 137: 1003-1010. http://dx.doi.org/10.1016/j. iep.2011.07.023

Folmer F, Jaspars M, Solano G, Cristofanon S, et al. (2009). The inhibition of TNF- $\alpha$-induced NF-kappaB activation by marine natural products. Biochem. Pharmacol. 78: 592-606. http://dx.doi.org/10.1016/j.bcp.2009.05.009

Horokova L, Licht A, Sandig G, Jakstadt M, et al. (2003). Standardized extracts of flavonoids increase the viability of PC12 cells treated with hydrogen peroxide: effects on oxidative injury. Arch. Toxicol. 77: 22-29.

Huber-Morath A (1970). Ebenus L. In: Flora of Turkey and the East Aegean Island, Vol 3. (Davis PH, eds.). Edinburgh University Press, London, 590-596.

Kim SC, Park SJ, Lee JR, Seo JC, et al. (2008). Cytoprotective activity of Glycyrrhiza radix extract against arsenite-induced cytotoxicity. Evid. Based Complement. Alternat. Med. 5: 165-171. http://dx.doi.org/10.1093/ecam/nem014

Lee JY, Jung HJ, Song IS, Williams MS, et al. (2009). Protective role of cytosolic 2-cys peroxiredoxin in the TNF- $\alpha$ induced apoptotic death of human cancer cells. Free Radic. Biol. Med. 47: 1162-1171. http://dx.doi.org/10.1016/j. freeradbiomed.2009.07.027

Lejeune FJ, Liénard D, Matter M and Rüegg C (2006). Efficiency of recombinant human TNF in human cancer therapy. Cancer Immun. 6: 6.

Leong OK, Muhammad TST and Sulaiman SF (2011). Cytotoxic activities of Physalis minima L. chloroform extract on human lung adenocarcinoma $\mathrm{NCl}-\mathrm{H} 23$ cell line by induction of apoptosis. Evid. Based Complement. Alternat. Med. Article ID 185064.

Levine A, Belenghi B, Damari-Weisler H and Granot D (2001). Vesicle-associated membrane protein of Arabidopsis suppresses Bax-induced apoptosis in yeast downstream of oxidative burst. J. Biol. Chem. 276: 46284-46289. http:// dx.doi.org/10.1074/jbc.M107375200

Min HY, Chung HJ, Kim EH, Kim S, et al. (2010). Inhibition of cell growth and potentiation of tumor necrosis factor-a (TNF- $\alpha$ )induced apoptosis by a phenanthroindolizidine alkaloid antofine in human colon cancer cells. Biochem. Pharmacol. 80: 
1356-1364. http://dx.doi.org/10.1016/j.bcp.2010.07.026

Natarajan N, Thamaraiselvan R, Lingaiah H, Srinivasan P, et al. (2011). Effect of flavonone hesperidin on the apoptosis of human mammary carcinoma cell line MCF-7. Biomed. Prev. Nutr. 1: 207-215. http://dx.doi.org/10.1016/..bionut.2011.07.001

Nikhil K, Sharan S, Chakraborty A and Roy P (2014). Pterostilbene-isothiocyanate conjugate suppresses growth of prostate cancer cells irrespective of androgen receptor status. PLoS One 9: e93335. http://dx.doi.org/10.1371/journal. pone.0093335

Ooi KL, Muhammad TST and Sulaiman SF (2013). Physalin F from Physalis minima L. triggers apoptosis-based cytotoxic mechanism in T-47D cells through the activation caspase-3- and c-myc-dependent pathways. J. Ethnopharmacol. 150: 382-388. http://dx.doi.org/10.1016/j.jep.2013.09.014

Pacifico S, Gallicchio M, Lorenz P, Potenza N, et al. (2013). Apolar Laurus nobilis leaf extracts induce cytotoxicity and apoptosis towards three nervous system cell lines. Food Chem. Toxicol. 62: 628-637. http://dx.doi.org/10.1016/j.fct.2013.09.029

Papi A, Farabegoli F, lori R, Orlandi M, et al. (2013). Vitexin-2-O-xyloside, raphasatin and (-)-epigallocatechin-3-gallate synergistically affect cell growth and apoptosis of colon cancer cells. Food Chem. 138: 1521-1530. http://dx.doi. org/10.1016/j.foodchem.2012.11.112

Ren S, Zhang H, Mu Y, Sun M, et al. (2013). Pharmacological effects of Astragaloside IV: a literature review. J. Tradit. Chin. Med. 33: 413-416. http://dx.doi.org/10.1016/S0254-6272(13)60189-2

Shoemaker M, Cohen I and Campbell M (2004). Reduction of MTT by aqueous herbal extracts in the absence of cells. J. Ethnopharmacol. 93: 381-384. http://dx.doi.org/10.1016/j.jep.2004.04.011

Stennicke HR and Salvesen GS (2000). Caspases - controlling intracellular signals by protease zymogen activation. Biochim. Biophys. Acta 1477: 299-306. http://dx.doi.org/10.1016/S0167-4838(99)00281-2

Tsai YL, Chiu CC, Yi-Fu Chen J, Chan KC, et al. (2012). Cytotoxic effects of Echinacea purpurea flower extracts and cichoric acid on human colon cancer cells through induction of apoptosis. J. Ethnopharmacol. 143: 914-919. http://dx.doi. org/10.1016/i.jep.2012.08.032

Wang SY and Jiao H (2001). Changes in oxygen-scavenging systems and membrane lipid peroxidation during maturation and ripening in blackberry. J. Agric. Food Chem. 49: 1612-1619. http://dx.doi.org/10.1021/jf0013757

Xiong Y, Wu X and Rao L (2015). Tetrastigma hemsleyanum (Sanyeqing) root tuber extracts induces apoptosis in human cervical carcinoma HeLa cells. J. Ethnopharmacol. 165: 46-53. http://dx.doi.org/10.1016/j.jep.2015.02.030

Yang HL, Chen SC, Chen CS, Wang SY, et al. (2008). Alpinia pricei rhizome extracts induce apoptosis of human carcinoma KB cells via a mitochondria-dependent apoptotic pathway. Food Chem. Toxicol. 46: 3318-3324. http://dx.doi.org/10.1016/j. fct.2008.08.003

Yu XQ, Xue CC, Zhou ZW, Li CG, et al. (2008). In vitro and in vivo neuroprotective effect and mechanisms of glabridin, a major active isoflavan from Glycyrrhiza glabra (licorice). Life Sci. 82: 68-78. http://dx.doi.org/10.1016/j.lffs.2007.10.019 